\title{
MagyarorsZágon tANUló KÍNAI HALLGATÓK TÁRSADALMI HÁTTERE ÉS BELÉPÉSI NEHÉZSÉGEI
}

\author{
PRIMECZ HENRIETT* - LI XUEYAN \\ Budapesti Corvinus Egyetem \\ Beérkezett: 2021. március 26., elfogadva: 2021. november 29.
}

Az ország nemzetköziesedő felsőoktatási rendszerében egyre több külföldi hallgató tanul hazánkban, közülük a kínai diákok alkotják a harmadik legnagyobb közösséget. Feltáró-kvalitatív kutatásunk azt vizsgálta, hogy milyen az itt tanuló kínai hallgatók családi háttere, mi motiválta őket, hogy Magyarországot választották felsőfokú tanulmányaikra, milyen első tapasztalataik vannak hazánkban. Az eredmények rámutattak arra, hogy a kínai hallgatók anyagi és társadalmi helyzete instabil. Magyarország legtöbbször kompromisszum eredményeként került kiválasztásra és a magyar kultúrába belépve gyakran elutasítást tapasztaltak.

Kulcsszavak: kínai hallgatók, magyar felsőoktatás, motiváció, kirekesztés

The internationalization of Hungarian higher education resulted in the growing number of international students studying here, among whom Chinese students form the third-largest group. Our explorative-qualitative research investigated the students' family background, their motivation to choose Hungary, their experiences encounter with Hungarian culture. The results have shown that Chinese students are from working-class or lower-middle-class families with financial constraints. The choice of Hungary was the result of a compromise in most cases. Chinese students faced numerous difficulties including language barriers and exclusion.

Keywordsः Chinese students, Hungarian tertiary education, motivation, exclusion

\footnotetext{
* Levelező szerző: Primecz Henriett, Budapesti Corvinus Egyetem, 1093 Budapest, Fővám tér 8.
}

E-mail: henriett.primecz@uni-corvinus.hu 


\section{Bevezetés}

$\mathrm{K}$ ína és Magyarország kapcsolata bővülőben van, amióta 2011-ben Ven Csia-pao kormányfő látogatást tett Budapesten és 16 közép-kelet-európai ország vezetőjével tárgyalt a gazdasági kapcsolatok élénkítéséről, amit az azóta beindult "One Belt One Road” (Új Selyemút) kezdeményezés még intenzívebbé tett (Turcsányi et al. 2019). A gazdasági kapcsolatok bővülése hatással van az oktatási kapcsolatok erősödésére is. Ráadásul az Európai Felsőoktatási Térség Tagjaként Magyarország azt a célt tűzte ki, hogy 2023-ra 40000 külföldi hallgató tanul majd Magyarországon, melynek elősegítése érdekében beindította a Stipendium Hungaricum programot, amelynek keretei között külföldi hallgatók kaphatnak tandíjtámogatást és ösztöndíjat, mely fedezi a magyarországi tanulmányi idejük alatt a lakhatási és megélhetési költségeiket. A program nagyon népszerű, exponenciálisan nő a jelentkezők száma, a 2017/2018-as tanévre már 3800 új hallgató kapott ilyen ösztöndíjat magyarországi tanulmányokra (Stipendium Hungaricum 2019; Li 2020). Ezt egészíti ki a külföldi hallgatók azon csoportja, amelyik tandíjat fizet és maga finanszírozza a megélhetési költségét. A nemzetközi hallgatók között a kínai hallgatók jelentős részt foglalnak el, a harmadik legnagyobb közösség a Magyarországon tanuló külföldiek között (Li 2020). Ez egyaránt köszönhető a kínai érdeklődésnek és a magyar fogadókészségnek.

Ugyanakkor keveset tudunk az itt tanuló kínai hallgatók családi hátteréről, motivációiról és első tapasztalatairól. A tanulmányban egy, a Magyarországon tanuló kínai hallgatók körében végzett interjúalapú kvalitatív kutatás néhány eredményét mutatjuk be. Öt egyetemi városban 26 kínai hallgatóval készítettünk narratív interjúkat, melyeket a grounded theory módszerrel elemeztünk. Az eredmények szerteágazóak, így ebben a cikkben csak azokat a részeket emeljük ki, amelyek az ide érkező kínai hallgatók társadalmi hátterére és a belépéskor tapasztalt nehézségeikre vonatkoznak.

\section{Elméleti megfontolások}

Bourdieu (1984) kimutatta, hogy nemcsak a gazdasági, hanem a társadalmi és a kulturális tőke is hozzájárul ahhoz, hogy az egyén melyik társadalmi osztályba tartozik. Khattab (2015) szerint a családok a gyermeknevelési gyakorlatukkal, az aspirációk és elvárások lefektetésével adják tovább kulturális tőkéjüket, és a jelentősebb kulturális tőkével bíró családok olyan szocializációt biztosítanak gyermekeik számára, amelyben a tanuláshoz való viszony és a jövőbeli karrieraspirációk sikeresebbé teszik a gyerekeiket azokban a versenyhelyzetekben, amelyekben az elithez tartozás eldől. Azok a családok, ahol alacsonyabb a gazdasági és kulturális tőkéhez való hozzáférés, nehezebben tudják megoldani, hogy a gyermekeik sikeresek legyenek az iskolában és később a munkájukban.

DiMaggio (1982) megkérdőjelezte a kulturális reprodukciós elméletet, és arra mutatott rá, hogy az alacsonyabb társadalmi-gazdasági körülmények közül érkező gyermekek is hozzájuthatnak kulturális tőkéhez az iskolarendszer által. Az alacsonyabb társadalmi osztályokból sikeres iskolai előmenetellel nyílik meg az esély a magasabb társadalmi osztályba kerülésre (Boyden 2013; Kalmijn-Kraaykamp 1996). Az ala- 
csonyabb társadalmi osztályokhoz tartozó családok is felismerték, hogy gyermekeik sikeresebbé válhatnak magasabb képzettség elérésével, és hasonló stratégiát igyekeznek folytatni, mint a magasabb társadalmi státuszú családok: gyermekeik tanulását támogatják, sokszor akár erőn felül is (Devine 2004; Goldthorpe 2007; Crul et al. 2017).

A nyelvtanulás, nyelvtudás kiemelkedően fontos eleme a társadalmi mobilitásnak, mert ez teszi lehetővé az országhatárokon túlmutató karriert. Mára az angol vált a „lingua francá"-vá, azaz angol nyelvtudással lehet nemzetközi szinten érvényesülni a legtöbb szakterületen (Bjørge-Whittaker 2014). Ez automatikus előnyt biztosít azoknak, akiknek angol az anyanyelvük és extra erőfeszítéseket igényel azoktól, akiknek viszont nem ez az anyanyelvük (Jackson-Primecz 2019). Ez a geopolitikai előny az angol anyanyelvüeken túl kedvez azoknak, akik könnyen és gyorsan hozzáférnek az angol minél jobb elsajátításához, például az iskolarendszerük által (lásd például a skandináv vagy holland angol nyelvoktatást), így a nyelvi hátrányuk nem számottevő. Minél távolabb van geopolitikailag egy ország az angol nyelvü központi országoktól, annál nagyobb erőfeszítést jelent a nyelv jó színvonalú elsajátítása, és annál nagyobb országon belüli különbéget hozhat létre az, hogy egy család megengedheti-e magának vagy sem, hogy a nyelvoktatásra nagyobb hangasúlyt fektessen.

A nyelvtudáshoz különösen jól hozzájárulhat egy jól megválasztott külföldi tanulmányi mobilitás, amely számos egyéb előnnyel is jár. Tágítja a horizontot, új készségeket segít elsajátítani és bővíti a kapcsolatokat, lényegében a jövőbeli munka számos aspektusát erősíti. Ugyanakkor ezek az előnyök nem jönnek azonnal. Van Bakel és munkatársai (2017) kimutatták, hogy amikor új országba kerül a mobil személy, rögtön számos nehézségbe ütközik, és segítségre van szüksége új élete beindításához. A fogadó országban élők jó néhány dologban egyszerűen tudnának segíteni, de ők ritkán érdekeltek abban, hogy újonnan érkezett idegeneknek segítsenek, néhányuk alkalmilag megteszi, de mivel a saját életük elfoglalja őket, nem ők válnak az érkezők fö támaszává. Ezzel szemben más külföldiek, különösen az azonos országból érkezettek nagyobb hajlandóságot mutatnak az újonnan érkezők megsegítésére. Segítik őket a praktikus problémák megoldásában, mert hasonló helyzetet ők is megéltek, és együttéreznek az újonnan érkezettekkel. Ez sokszor ahhoz vezet, hogy a külföldiek saját országuk szerinti csoportokba rendeződnek, amit a szakirodalom expatrióta buboréknak is nevez (Nguyen-Akbar 2017). Ehhez járul hozzá a fogadó ország kultúrájának nyitottsága is: a külföldiek könnyebben boldogulnak azokban az országokban, ahol a társadalom befogadóbb (Fritzpatrick 2017). Magyarországon azonban az elöítéletesség folyamatosan problémát jelent, és rendszeresen kimutatják, hogy a magyar társadalom a kirekesztőbbek közé tartozik az Európai Unióban (European Commission 2015).

\section{A kutatás módszertana: adatgyüjtés és elemzés}

A téma feltáratlansága miatt narratív interjúkon alapuló kvalitatív kutatást végeztünk 2019 novemberében olyan kínai hallgatók körében, akik Magyarországon tanulnak (Czarniawska 2014; Kvale 1996). Az interjúkat kiegészítendő, megfigyeléseket végeztünk az interjúalanyok lakókörnyezetében az interjúk előtt, alatt és után, és kutatási naplót vezettünk a megfigyeléseinkről és kialakuló értelmezéseinkről (Gaggiotti et al. 2017).

A célzott mintavétel során törekedtünk arra, hogy a lehető legváltozatosabb demográfiai jellemzői legyenek az interjúalanyoknak, azaz maximális variáció volt a 
cél (Horvátb-Mitev 2015). A demográfiai jellemzők, amelyek alapján törekedtünk a sokszínűségre, a következők voltak: nem (nő, férfi), képzési szint (alap, mester, $\mathrm{PhD}$ ), támogatási forma (ösztöndíjas, önköltséges), földrajzi származási hely Kínában (kelet, közép, nyugat), oktatási hely Magyarországon (Budapest, Pécs, Szeged, Debrecen, Miskolc), etnikai státusz Kínában (többségi, kisebbségi), családi állapot (házas, nem házas), Magyarországhoz kapcsolódás (van vagy nincs családja, rokona Magyarországon). Minden dimenzióban sikerült több interjúalanyt találni. Képzettségi szint szerint 11 alapszakos, 12 mesterszakos és négy $\mathrm{PhD}$-hallgató vett részt a kutatásban. Képzési területek szerint 11 bölcsész és társadalomtudományi, kilenc természettudományi és nyolc orvosi területen tanuló hallgatót sikerült elérni. A nemek aránya enyhén a férfiak felé billent 17 férfi és 14 női résztvevővel. Végül 14 ösztöndíjas és 17 önköltséges hallgató volt a mintában, de az önköltségesek közül hárman csökkentett díjat fizethettek. Összességében minden lényeges szempont szerint szórt a minta.

Az interjúalanyok számát az elméleti telítettség határozta meg (Horvátb-Mitev 2015), a biztonság kedvéért az elméleti telítettség elérése után még 4-5 interjút készítettünk. A személyes interjúk kínai nyelven zajlottak. Az interjúk időtartama 60-90 perc volt. Az elemzés kínaiul történt grounded theory módszerrel (Mitev 2012; Strauss-Corbin 1998). A felhasznált idézeteket először angolra fordítottuk, majd az ebben a cikkben szereplö idézeteket angolból fordítottuk magyarra.

\section{Eredmények}

Minden interjú a hallgató családi hátterével, gyerekkorával kezdődött azzal a céllal, hogy kiderüljön, miért gondolkodtak nemzetközi tanulmányokban és miért éppen Magyarországot választották.

\section{Magyarországon tanuló kinai hallgatók családi háttere és motivációja}

Egy interjúalany kivételével mindenki szívesen beszélt a családi hátteréről, és konzisztens mintázat rajzolódott ki. Az itt tanuló kínai hallgatók munkásosztálybeli vagy maximum alsó középosztálybeli családokból származtak. Az apák közül nyolcan kisvállalkozást vezetnek, öten fizikai munkások, 12-en közszférában dolgoznak, és van munkanélküli is közöttük. Az anyák munkái hasonlóak voltak, bár még nagyobb arányban kisvállalkozást vezettek és háztartásbeli anya is több volt. A legtöbbjük szüleinek nincs felsőfokú végzettsége. Azoknak az interjúalanyoknak, akiknek a szülei diplomások, mind alacsonyabb jövedelmű munkát végeznek, például tanárok. Bár a kutatás fókusza elsősorban a kulturális töke megléte vagy hiánya volt, és a kínai kultúra is tabuként kezeli az anyagi kérdések nyílt megbeszélését, az interjúalanyok túlnyomó többsége plasztikusan jellemezte a család nehéz anyagi helyzetét. Volt, aki említette, hogy gyermekkorában munkásszállón éltek, volt, aki úgy jellemezte a családi életkörülményeit, hogy nagyon szegény körülmények között élt. Az interjúalanyok kínai lakóhelyei is sokat elárultak, többnyire eldugott kisfalvakban élt a családjuk, és még a nagyvárosiak is a város azon részén, amire nem az előkelő környék volt a legjobb elnevezés.

Bár az interjúalanyok mindegyike anyagi nehézségekről számolt be, a többségük támogatást kapott a szüleitől a tanulással kapcsolatban, és biztatást kaptak a szorgalmas tanulásra, remélve a gyermekek társadalmi felemelkedését, amennyiben sikeresen végzik 
tanulmányaikat. Különösen az angol tanulást szorgalmazták a szülők, még olyan is, aki maga egyáltalán nem beszélt angolul.

Az egyik interjúalany elmondta, hogy abban a társadalmi környezetben, ahol felnőtt, a lányok képzésére nem fektetnek hangsúlyt, de az apja támogatta őt is, hogy tanuljon. Egy másik interjúalany a nagymamájáról beszélt elismeréssel, aki megtanította őt a kaligráfiára, ami Kínában a műveltség jele. Ezenkívül különórákra is jártak a hallgatók, sportra, zenére, táncra, művészeti tevékenységre annak ellenére, hogy családjaik anyagi helyzete instabil volt. Bár a hobbi szintnél többre értékelték a szülők azokat a különórákat, ami közvetlenül hozzájárult a gyerek iskolai előmeneteléhez, némelyikük olyan különórákat is finanszírozott, ami a társadalmi helyzetüket meghaladóan költséges volt, például drága egyéni zeneórákat.

Emellett azt is több interjúalany elmondta, hogy gyermekkoruk egy része felügyelet nélkül zajlott. A szülők sokat dolgoztak, hogy biztosítsák a család megélhetését, és hol nagyszülőkre bízták őket, hol teljesen egyedül hagyták őket. A legtöbb családban nem volt jellemző a kulturális fogyasztás. Ezt néhány interjúalany magától elsajátította fiatal felnőtt korában, például egyikük nagy színházrajongó lett, míg mások a mai napig kulturális fogyasztás nélkül élnek. A külföldi továbbtanulás sokukat foglalkoztatta, melynek kapcsán elmondható, hogy Magyarország a saját társadalmi helyzetüket tekintve egyértelműen lehetőségként jelent meg.

„Nézzük az én példámat. Kina egy eldugott vidéki területéröl jövök. Apám nem tudott dolgozni egy betegség miatt, így anyám keresett mindannyiunkra. Nem minden nemzetközi diák jön gazdag családból. Nem mindenki van a társadalom csúcsán Kínában. Nagyon sok teljesen átlagos család, mint a miénk, az alsó középosztályból arról álmodozik, hogy külföldre megy tanulni. Magyarország egy lehetöség ebben a társadalmi közegben."

Hozzátéve, hogy legtöbben Angliába vagy Amerikába akartak továbbtanulni, azonban nem volt korlátlan anyagi lehetőségük, illetve volt, aki nem ért el 6,5 pontot az IELTS nyelvvizsgán, ami elengedhetetlen az angliai tanuláshoz, Magyarországon viszont elkezdhette a tanulmányait alacsonyabb pontokkal is. ${ }^{1}$ Többüket felvették valamelyik angol egyetemre, ennek ellenére mégis Magyarországon kezdték meg tanulmányaikat.

„A szüleim már finanszíroztak nekem egy mesterképzést, és szégyelltem volna további pénzt kérni doktori képzésre, így elutasitottam az angol lehetöséget és elkezdtem a $\mathrm{PhD}-t$ Magyarországon ösztöndijjal."

A tandíj és a megélhetési költségek különbsége Anglia és Magyarország között annak is szempont volt, aki nem volt ösztöndíjas. Az orvosi képzés például nagyon drága, és a külföldieknek fizetendő hazai tandíj a megélhetési költségekkel együtt még elfogadható volt, szemben az angliai tandíjjal és megélhetési költségekkel. Bár sokan merő kompromisszumból jöttek Magyarországra, volt, aki említette, hogy a Nobel-díjasok magas

1 B2 szintű középfokú nyelvvizsga körülbelül ekvivalens az IELTS 5,5-6,5 ponttartománnyal, C1 felsőfokú szint 6,5 felett kezdődik. Ez azt jelenti, hogy Angliában és sok nyugati egyetemen elvárják a felsőfokú nyelvtudást, míg Magyarországon középfokú nyelvtudással is elkezdhetnek felsőfokú tanulmányokat a hallgatók. 
száma győzte meg arról, hogy jó lehet az egyetemi képzés Magyarországon. Más pedig csak itt talált olyan képzést, ami legjobban érdekelte, sehol máshol.

„Találtam egy gazdaságpolitika mestert, és pont ez érdekelt. Az alapszakos jogi tanulmányaimra és a jelenlegi piaci politikára nagyon jól jött ez a mester. Olyan kurzusaim vannak, ahol a jogi tudásomat is jól hasznositom és továbbfejlesztem. Ez volt a legfontosabb a választásomkor, hogy a jövöbeli karrieremet mi szolgálja."

\section{Belépési nebézségek}

A kínai hallgatók nagy reménnyel és optimizmussal érkeztek Magyarországra, és azonnal sok nehézséggel szembesültek. Többen azután döntöttek a külföldi tanulmányok mellett, hogy szembesültek azzal, hogy mennyire más életet lehet élni a nagyobb városokban, külföldi országokban, mint a szülőhelyükön. Egyikük például egy vidéki területről Sanghajba került, és ez olyan gyökeres változást hozott az életében, hogy bátran bevállalt egy európai tanulmányt is. Másikuk egy rövid diákcserén volt Franciaországban, és ezután mindenképpen külföldön, az USA-ban vagy Európában akart továbbtanulni. Az egyik interjúalany Japánba került a szülei révén, és ott ismerkedett meg egy művésszel, és ez a találkozás erősítette meg benne, hogy művészetet szeretne tanulni külföldön. A másiknak magyar származású volt a középiskolai angol tanára, és ő mesélt az országról, így kapott kedvet hozzá.

A belépés ezzel együtt nagyon nehéz volt a magyar felsőoktatásba és mindennapokba. Az itt tartózkodás kezdete minden interjúalanynak több-kevesebb, kisebb vagy súlyosabb nehézségekkel járt. Az interjúalanyok közel fele nem beszélt jól angolul, ez is volt az egyik akadálya, hogy Nyugatra menjenek továbbtanulni. A másik nagy nehézség, különösen a fiatalabb hallgatók esetében, hogy az egyik pillanatról a másikra hatalmas önállóságot nyertek, a felsőfokú tanulmányok során a feladataikat és tanulási idejüket maguknak kellett meghatározniuk, csak a határidők voltak adottak, és ez nagy váltást jelentett sok hallgatónak, de különösen nagy kihívást jelentett azoknak a hallgatóknak, akik korábban még szabályozottabb rendszerből érkeztek.

„Kinában minden nap találkoztunk a tanárainkkal. Itt nincsenek mindig a tanárok a nyakunkon, élvezzük a szabadságot. Azonban senki sem sürgeti, bogy tanuljunk."

A magányosság különösen súlyosan érintett néhány itt tanuló kínai diákot. Távol minden emberi kapcsolattól, amit ismernek (család, barátok), ismeretlen környezetben, és az új kapcsolatok kialakítása nem volt zökkenőmentes. Sokan szórakozóhelyeken próbálnak feloldódni, azonban az átmulatott éjszakák nem kedveznek a tanulásnak, és nem is mindig vezetnek valódi emberi kapcsolatokhoz. Volt, aki sajnálattal számolt be arról, hogy ezt mennyire rosszul csinálta az ideérkezése elején.

„Élveztem a szabadságot, a kényelmes életet az elején, aztán megbuktam az elsö vizsgán. Kerestem az okokat. Aztán megértettem, hogy nekem kell kialakitani a szabályokat, nekem kell az időmmel gazdálkodnom, anélkül, hogy a szülök felügyelnének, minden rajtam múlik." 
A kínai hallgatók azzal a szándékkal érkeztek Magyarországra, hogy elmerüljenek a kultúrában, integrálódjanak. Mindannyian arról számoltak be, hogy komoly visszautasításokat éltek meg a magyar hallgatók részéről. Egyik hallgató egy projektmunkáról panaszkodott, hogy kihagyták belőle. Mások megalázó xenofób viselkedésről számoltak be. A hallgatótársak is nagyon kellemetlenül viselkedtek egyes helyzetekben.

„Rengeteg kibivással szembesültem. Egy projektcsoportban voltam magyarokkal, egyedül kinaiként. A csoporttársaim megbeszéltek mindent magyarul. Ez nagyon elkeseritett."

„Nagyon sok kinaiellenes viselkedést tapasztaltunk. Például volt úgy, bogy buszmegállóba mentünk, és ott leköptek minket."

"Az elején olyan volt, mintha UFO-k lennénk. Minden alkalommal, amikor beléptünk a terembe mindenki minket bámult."

Sok kínai hallgató úgy érezte, hogy jobban megérti magát a kínai társaival. Volt, aki azzal a szándékkal jött Magyarországra, hogy nem akar a kínai kör tagja lenni, de néhány visszautasítás után valakivel muszáj volt kapcsolatban lenni, így a kínai hallgatókhoz fordult. Volt, aki annyira elveszett volt, hogy szüksége volt támogatóra, és ezt a magyar társaktól nem kapta meg.

"Elsöévesként muszáj azokkal beszélned, akik basonló belyzetben vannak. Nagyon megnyugtató volt velük beszélni."

Emellett volt, aki csak sodródott, mivel néhányszor visszapattant a magyar és más nemzetközi hallgatókról, maradtak így a kínai társak. Olyannyira, hogy csoportmunkában egymást választották, és ugyanúgy kizárták a többieket azzal, hogy a feladatot kínaiul beszélték meg. Volt, aki az elején egyszerüen csak nehezen talált közös témát a potenciális új ismerősökkel, míg a kínaiakkal mindig volt miről beszélni. Különösen azoknak a hallgatóknak, akiknek nyelvi nehézségeik voltak, megkönnyebbülés volt, hogy az anyanyelvükön beszélhetnek.

\section{Konklúzió és javaslatok}

A kutatás rávilágított, hogy kevésbé felkészült hallgatók pályáznak és nyernek felvételt Magyarországra, mint Nyugatra. Ez geopolitikai adottság, ugyanakkor társadalmi igazságosság szempontjából fontos megtartani a motivált hallgatókat, akik a családjuk kedvezőtlenebb társadalmi helyzetéből adódóan nem elég felkészültek, nem tudnak elég jól angolul és az anyagi lehetőségeik sem teszik lehetővé, hogy saját erőből beérjék a jobb társadalmi környezetből érkező társaikat. Érdemes tehát megfontolni, hogy célzott nyelvoktatást biztosítsanak az ide érkező hallgatóknak. Emellett az érkezési nehézségek, amelyek minden interkulturális váltásnál megjelennek, fontos eredménye volt a kutatásnak. Ezen sokat segíthetne egy intenzív „buddy program” (hallgatótárs támogató program), ami sok más nemzetközi hallgatói mobilitás esetén természetesen rendelkezésre áll. A magyar hallgatók interkulturális ismereteit is bővíthetné, ha aktívabb kapcsolatban lennének a felsőoktatási intézményükbe érkező kínai hallgatókkal. 
Az alapprobléma - hogy Magyarország kevésbé vonzó továbbtanulási hely, mint a nyugati országok - megmarad, azonban jobb interkulturális tapasztalatokat is nyújthatna az ország az ide érkező kínai hallgatóknak.

\section{IRODALOM}

Bakel, M. van, Oudenhoven, J. P. van \& Gerritsen, M. (2017) Expatriate Contact with a Local Host: An Intervention to Increase Social Support. Human Resource Development International, Vol. 20. No. 3. pp. 215-235. DOI: 10.1080/13678868.2016.1248720

Bjørge, A. K. \& Whittaker, S. (2014) Language Management. In: Gherke, B. \& Claes, M. T. (eds) Global Leadership Practices. A Cross-cultural Management Perspective. MT, New York, Palgrave. pp. 51-66.

Bourdieu, P. (1984) Distinction: A Social Critique of the Judgement of Taste. London, Routledge.

Boyden, J. (2013) 'We're Not Going to Suffer Like This in The Mud': Educational Aspirations, Social Mobility and Independent Child Migration Among Populations Living in Poverty. Compare: A Journal of Comparative and International Education, Vol. 43. No. 5. pp. 580-600. DOI: 0.1080/03057925.2013.821317

Crul, M., Schneider, J., Keskiner, E. \& Lelie, F. (2017) The Multiplier Effect: How the Accumulation of Cultural and Social Capital Explains Steep Upward Social Mobility of Children of Low-Educated Immigrants. Ethnic and Racial Studies, Vol. 40. No. 2. pp. 321-338. DOI: 10.1080/01419870.2017.1245431

Czarniawska, B. (2014) Social Science Research: From the Field to the Desk. London, SAGE Publication.

Devine, F. (2004) Class Practices: How Parents Help Their Children Get Good Jobs. Cambridge, Cambridge University Press. https://doi.org/10.1017/CBO9780511488771

DiMaggio, P. (1982) Cultural Capital and School Success: The Impact of Status Culture Participation on the Grades of U.S. High School Students. American Sociological Review, Vol. 47. No. 2.pp. 189-201. https://doi.org/10.2307/2094962

European Commission (2015) Special Eurobarometer 437, Discrimination in the EU in 2015. https://data.europa.eu/euodp/sv/data/dataset/S2077_83_4_437_ENG. [Letöltve: 2017. 09. 07.]

Fritzpatrick, F. (2017) Taking the "Culture" Out of "Culture Shock" - A Critical Review of Literature on Cross-Cultural Adjustment in International Relocation. Critical Perspectives on International Business, Vol. 13. No. 4. pp. 278-296. DOI: 10.1108/ cpoib-01-2017-0008

Gaggiotti, H., Kostera, M. \& Krzyworzeka, P. (2017) More than a Method? Organisational Ethnography as a Way of Imagining the Social. Culture and Organization, Vol. 23. No. 5. pp. 325-340. DOI: 10.1080/14759551.2016.1203312

Goldthorpe, J. H. (2007) On Sociology. Volume Two: Illustration and Retrospect (2nd edition). Stanford, Stanford University Press.

Horváth D. \& Mitev A. (2015) Alternatív kvalitatív kutatási kézikönyv. Budapest, Alinea.

Jackson, T. \& Primecz, H. (2019) Cross-Cultural Management Studies and the Englishization of Scholarly Communication: A Paradox. International Journal of CrossCultural Management, Vol. 19. No. 2. pp. 115-119. DOI: 10.1177/1470595819865095 
Kalmijn, M. \& Kraaykamp, G. (1996) Race, Cultural Capital, and Schooling: An Analysis of Trends in the United States. Sociology of Education, Vol. 69. No 1. pp. 22-34. https://doi.org/10.2307/2112721

Кнаттав, N. (2015) Students' Aspirations, Expectations, and School Achievement: What Really Matters? British Educational Research Journal, Vol. 41. No. 5. pp. 731-748. DOI: 10.1002/berj.3171.

Kvale, S. (1996) InterViews. An Introduction to Qualitative Research Writing. Thousand Oaks, CA: Sage.

LI, X. (2020) Chinese Students Choosing Hungarian Tertiary Education: A Systematic Review. East Asia, Vol. 37. pp. 317-330. https://doi.org/0.1007/s12140-020-09333-y

Mitev A. (2012): Grounded theory, a kvalitatív kutatás klasszikus mérföldköve. Vezetéstudomány, Vol. 43. No. 1. pp. 17-30.

Nguyen-Akbar, M. (2017) The Formation of Spatial and Symbolic Boundaries among Vietnamese Diasporic Skilled Return Migrants in Ho Chi Minh City, Vietnam. Sociological Perspectives, Vol. 60. No. 6. pp. 1115-1135. DOI: $10.1177 / 0731121417700113$

Stipendium Hungaricum (2019) Scholarship Program. Call for Application. http://www. stipendiumhungaricum.hu/ [Letöltve: 2019. 12. 10.]

Strauss, A. \& Corbin, J. M. (1998) Basics of Qualitative Research: Techniques and Procedures for Developing Grounded Theory. (2nd Edition.) Thousand Oaks, California: Sage.

Turcsányi, R., Karásková, I., Matura, T. \& Šimalčí́x, M. (2019) Followers, Challengers, or By-Standers? Central European Media Responses to Intensification of Relations with China. Intersections. East European Journal of Society and Politics, Vol. 5. No. 3. pp. 49-67. DOI: 10.17356/ieejsp.v5i3.564

A cikk a Creative Commons Attribution 4.0 International License (https://creativecommons.org/licenses/ by/4.0/) feltételei szerint publikált Open Access közlemény, melynek szellemében a cikk bármilyen médiumban szabadon felhasználható, megosztható és újraközölhető, feltéve, hogy az eredeti szerző és a közlés helye, illetve a CC License linkje és az esetlegesen végrehajtott módosítások feltüntetésre kerülnek. (SID_1) 